\title{
Eco-innovative competencies of mining engineers in the context of environmental management system requirements
}

\author{
Sergey Yu. Trapitsin ${ }^{1}$, Zoya V. Apevalova ${ }^{1}$, Marina A. Loshchilova ${ }^{2 *}$, Liliia Al. \\ Leonova $^{3}$, Irina $B$. Trofimova ${ }^{1}$ and Marina $V$. Yeroma ${ }^{1}$ \\ ${ }^{1}$ Institute of Economics and Management, Herzen State Pedagogical University, Saint-Petersburg, \\ Russia. \\ ${ }^{2}$ Yurginsky Technological Institute (branch of Tomsk polytechnic university), Yurga, Russia. \\ ${ }^{3}$ National Research Tomsk Polytechnic University, Tomsk, Russia.
}

\begin{abstract}
The article is devoted to the analysis of mining engineers' ecoinnovation training key components associated with the formation of special knowledge and skills in the field of coal mining enterprises environmental management. The issues of the eco-innovation activities and the objectives of environmental management at coal mining enterprises are consistently considered. The article presents the examination of general and special requirements for the environmental education of mining engineers, which are to become the basis for the sustainable development of engineering projects in coal-mining industry.
\end{abstract}

\section{Introduction}

Innovation is a fundament of the modern economy development. The Government of Russian Federation, being aware of the importance of modernizing enterprises whose activities are likely to exercise significant influence on the environment, postulates the need for innovative reorientation of such company's strategies. However, one of the key problems faced by a manager who uses the potential of digital economy and knowledge economy is a significant shortage of human resources able to develop, experimentally test, and implement innovations.

The sphere of environmental protection, design and development of the new products and technologies, methods and tools, aimed at improving the environmental quality of production and everyday life is no exception. The investigating purposes and requirements of eco-innovation management is a complex process, since a specialist in this field must possess a wide range of environmental, economic and engineering knowledge. It could be argued that no educational institution in Russia currently trains specialists with crossdisciplinary eco-innovative competencies described. However, it is necessary to promote the system of professional education of mining engineers in this regard, otherwise the innovative request for further development of the society will not be fulfilled.

* Corresponding author: marisha20@bk.ru 
Environmental innovations in the coal mining sector relate, among other things, to the issues of modernizing the industry, and therefore include: development of energy efficiency and conservation technologies; effective project management, including for reclamation of degraded lands; introduction of technological processes' new algorithms; minimization of the negative impact on the enterprise personnel through using of the technical, technological, and educational innovations; formulation of highly effective eco-innovation and sustainability training programs for managers and mining engineers, etc.

Evidently, without the development of fundamental and conceptual grounds for special eco-innovative training of mining engineers, environmental management of coal mining enterprises can become a field of declarative statements rather than a meaningful activity. The research objectives are as follows:

- Analyze the potential impact of coal mining enterprises' activities on the environment;

- Identify the environmental innovations areas of application that may contribute to the sustainable development of coal mining enterprises;

- Classify key eco-innovation competencies of mining engineers;

- Identify key problems of the mining managers' eco-innovative training and specify areas of improvement in the eco-management education.

\section{Methods}

The research is based on the following scientific methodology: analysis of text sources on the research topic, research of environmental management public documents of coal mining enterprises and comparative analysis of terminology in different concepts of eco-innovation management. This paper addresses the above-mentioned problems using the method of classification of eco-innovation competencies of mining managers. These competencies are distributed in qualitatively different areas of environmental activity at coal mining enterprises. Being the result of the authors' new approach, this classification embraces not only new techniques for field development and exploitation but also any innovations contributing to rational use of natural resources and minimization of enterprise negative impact on the environment and the staff.

The competence in the field of eco-innovation and environmental management of future mining engineers was assessed with the method of determination of the coefficient, which characterizes the level of professional training based on the weight, assigned by students of "Mining" faculty (specialization No. 21.05.04) of Yurginsky Technological Institute to each of the indicators during self-assessment session.

\section{Factors affecting the environment in the coal mining industry}

The majority of modern managers and engineers working in innovative areas of the Russian economy do not possess a sufficient level of environmental competence. This conclusion is a product of the analysis of numerous examples of innovative management poor decisionmaking process and its negative consequences. The reason for low environmental literacy is both an imperfect system of continuing professional education, and undeveloped methodological foundations for sustainable development of enterprises [1]. Among other things, there is a paradoxical situation in the eco-innovation sphere: on the one hand, there are quite a lot of environmental innovations under development, increasing in demand both in production and in everyday life; on the other hand, their application is most often due to the popular "trend" toward innovation. At the same time, any decisions in the field of 
environmental management require careful study in accordance with the technologies for making environmentally significant decisions.

The Russian Federation has a strong raw material base of coal, ranking second in the world after the United States in terms of reserves (274 billion tons). Among other environmental problems of the coal mining industry, the issue of ensuring environmental safety remains the leading one [2]. Moreover, given the high level of risk to the life and health of employees of these types of enterprises, it should be stated that the external and internal tasks of environmental management under such conditions are equivalent in terms of the severity of consequences in the event of deviations from the desired indicators. Thus, in the area of environmental impact, the coal mining industry is determined by the negative influence on biodiversity. This activity entails the destruction of animal habitats and determines the environmental impact of significant biogeocenoses, which remain affected by coal mining through physical and chemical factors of activity.

The promotion of nature-friendly coal mining concept is becoming increasingly important in a number of issues related to the innovation of management processes for coal mining enterprises. In the process of improving management systems economic actors set themselves new goals for minimization of the negative impact on the environment and personnel [3]. The implementation of these goals is primarily related to advanced achievements in the eco-innovation sphere, the capabilities of coal mining enterprises, and the priorities for the development of the "green economy" in the country and in the world [4].

\section{Environmental management of coal mining enterprises and innovative thinking of mining engineers}

The clean technology market today is represented by a wide range of products, services, and processes that provide productivity while reducing costs, including "environmental costs", by minimizing negative environmental impact [5]. So, why is there not enough experience in applying the requirements established by environmental legislation? Why are expensive environmental management projects, which provide proactive and effective activities for the implementation of the company's own programs, in such a great demand? The answer, we assume, lies in the specifics of conducting coal-mining activities. For example, while the problems of restoring degraded land after open-pit mining operations on horizontal and flat-falling fields partially have solutions, there are no approved regulations that require existing and newly opened enterprises, which operate on inclined and steeply falling fields, to reclaim residual quarries and implement the restoration [6]. Similar examples can be cited from the sphere of personnel security, and the use of "technologies of the future economy" [7].

It is important to trace the correlation between the lines of development of ecoinnovations for environmental project management at coal mining enterprises and the required competencies from mining engineers (table.1). The competencies, which are discussed in the table, are based on the results of investigation of eco-innovative technologies, made by one of the authors of this article [8]. It should be noted that innovations in this particular case could be defined, firstly, as fundamentally new technologies, techniques, methods, etc., and, secondly, as the application of existing innovations previously not applied.

Table 1. Classification of mining engineers" competencies in relation to the development and implementation of eco-innovations at coal mining enterprises [8]. 


\begin{tabular}{|c|c|c|}
\hline № & $\begin{array}{l}\text { Areas of development and } \\
\text { implementation of eco-innovations } \\
\text { at coal mining enterprises }\end{array}$ & Mining engineers' competencies \\
\hline 1 & $\begin{array}{l}\text { New methods of generating } \\
\text { energy, which could be applied to } \\
\text { material objects of management. }\end{array}$ & $\begin{array}{l}\text { Ability to use solar, wind, hydro-marine, biofuel, } \\
\text { geothermal, etc. energy sources }\end{array}$ \\
\hline 2 & New approach to energy storage & $\begin{array}{l}\text { Ability to develop and introduce new energy storage } \\
\text { devices, hybrid energy storage systems; ability to } \\
\text { improve existing energy storage devices }\end{array}$ \\
\hline 3 & $\begin{array}{l}\text { Energy infrastructure of coal } \\
\text { mining enterprises }\end{array}$ & $\begin{array}{l}\text { Ability to assess the efficiency of the energy } \\
\text { infrastructure of enterprises }\end{array}$ \\
\hline 4 & Energy efficiency in enterprises & $\begin{array}{l}\text { Ability to employ techniques to improve energy } \\
\text { efficiency of enterprises through the use of new } \\
\text { materials, construction technologies, cargo logistics } \\
\text { techniques, etc. }\end{array}$ \\
\hline 5 & $\begin{array}{l}\text { Transportation of personnel. Coal } \\
\text { transportation. }\end{array}$ & $\begin{array}{l}\text { Ability to design new efficient logistics network } \\
\text { schedules, which minimize delays and optimize the } \\
\text { use of employees ' working time }\end{array}$ \\
\hline 6 & $\begin{array}{l}\text { Water and wastewater generated } \\
\text { during and as a result of mine } \\
\text { operations. }\end{array}$ & $\begin{array}{l}\text { Ability to assess the results of environmental impact } \\
\text { monitoring when designing the field development and } \\
\text { operation processes }\end{array}$ \\
\hline 7 & $\begin{array}{l}\text { Air and the environment (as the } \\
\text { most important areas where the } \\
\text { use of innovations ensures the } \\
\text { survival of not only employees, } \\
\text { but also people living in the area } \\
\text { affected by the negative } \\
\text { consequences of activities) }\end{array}$ & $\begin{array}{l}\text { Ability to implement introduction of new technologies } \\
\text { in different spheres such as cleaning and safety } \\
\text { improving, emissions controlling, compliance with } \\
\text { requirements monitoring (including those developed } \\
\text { by the company itself) }\end{array}$ \\
\hline 8 & Industry / Productive activity & $\begin{array}{l}\text { Ability to implement eco-innovations at every stage of } \\
\text { development of the company's environmental } \\
\text { management system: planning, organizing and mining } \\
\text { engineers' competencies controlling the activities of } \\
\text { the company as a whole and its individual divisions } \\
\text { (including coal mining fields) }\end{array}$ \\
\hline 9 & Coal mining waste & $\begin{array}{l}\text { Ability to develop a technological cycle of } \\
\text { management that involves the inclusion of innovative } \\
\text { forms of recycling and waste management }\end{array}$ \\
\hline
\end{tabular}

According to the results of the analysis presented in the Table 1, it is possible to draw a conclusion that professional mining engineers should have expert knowledge of:

-Modern methods of reduction of all types of emissions in the designed objects;

-Engineering principles of the processes of recycling and reusing of materials obtained as a by-production the course of coal mining;

-Quality control indicators of coal mining operations, as well as, quality indicators of the environment affected by the enterprise;

-Purposes of designing complex processes, which reduce energy consumption;

-Modern methods of improvement the efficiency of water consumption;

-Modern methods of incorporation of engineering objects in programs and strategies for comprehensive development of the territory;

-Innovative approaches to rational consumption of both natural resources (minimizing the volume of formed dumps, including), and energy, water, and fuel;

-Modern methods of reclamation of land degraded as a result of coal mining, inclusion of land restoration tasks in the mining project as a key stage of field development. 
At the same time, any coal mining company, primarily, strives for economic efficiency of management. Distinctive philosophy of "green" coal mining.therefore, harmonizes the two conflicting goals of providing the economy with resources and securing relative safety for the environment and employees of the organization [9]. In this article, we argue that eco-innovation management can act as a means of such harmonization. It is obvious that the very meaning of eco-innovation management of an enterprise implies special crossdisciplinary competencies of key specialists who determine the content of economic activity [10]. Mining engineers can also be considered such specialists on a full basis.

\section{Assessment of the level of eco-innovation competencies of mining engineers}

Among other key competencies of mining engineers identified in the state educational standard of higher education, for the purposes of this study, special attention should be paid to such as [2]:

1. Ability to introduce new techniques and technologies for mining and processing of minerals and to assess technological risks when applying new approaches;

2. Ability to select environmental health and safety management system;

3. Ability to apply the safety rules of technological processes, as well as the ability to assess critically the production situation in order to identify areas for continuous improvement of the set of safety measures;

4. Ability to develop and implement mining projects using geotechnological methods using resource-saving, low-energy and low-operational technologies, projects for the integrated use of mineral resources and environmental protection.

The first and fourth of these competencies can be attributed to eco-innovations, as they partially reflect the content of the Table 1 . The practical assessment of the level of ecoinnovation competencies, as was mentioned above, was conducted by means of the method of the coefficient determination.

In order to establish the set of measures to improve the professional training of mining engineers, it is important to ascertain three factors: Estimation of significance of key ecoinnovation competences declared by future specialists;Rank of preference for each competence;Estimation of the quality of assimilation of the eco-innovation module within the university educational program.

The combination of these assessments allows us to determine the urgency of developing this competence, and, consequently, the necessity of introducing of new components in the training program of future specialists.

We used the following ranking system to determine such characteristic as the urgency of competence development:

Groups:

-it is necessary to pay special attention, significant improvements of the characteristic are required;

-there are serious drawbacks, the characteristic needs to be improved;

-correction of certain drawbacks and improvement of the characteristics required;

-it is possible to improve this characteristic;

-there are opportunities for further improvement of the characteristic.

Levels:

0 - with an unclear preference level;

1 - with a high preference level;

2 - with an average preference level;

3 - with a low preference level. 
The results of the ranking are represented in the Table 2. The stated figures constitute the average parameters obtained in the survey of 40 students of the specialty "Mining" and rounded to the nearest values.

Table 2. Assessment of the significance, real assimilation quality, and preference rank of mining engineers ' eco-innovation competencies

\begin{tabular}{|c|c|c|c|c|c|}
\hline$\#$ & $\begin{array}{l}\text { Eco-innovative } \\
\text { competencies of mining } \\
\text { engineers }\end{array}$ & $\begin{array}{l}\text { Estimation } \\
\text { of } \\
\text { significance } \\
(\mathrm{OZ})\end{array}$ & $\begin{array}{l}\text { Estimation of } \\
\text { the quality of } \\
\text { competencies } \\
\text { assimilation } \\
\text { (MO) }\end{array}$ & $\begin{array}{l}\text { Maximum } \\
\text { estimation of } \\
\text { the quality of } \\
\text { competencies } \\
\text { assimilation }\end{array}$ & $\begin{array}{l}\text { Preferenc } \\
\text { e rank }\end{array}$ \\
\hline 1 & $\begin{array}{l}\text { Ability to use solar, wind, } \\
\text { hydro-marine, biofuel, } \\
\text { geothermal, etc. energy } \\
\text { sources }\end{array}$ & 3 & 3 & 4 & 1.2 \\
\hline 2 & $\begin{array}{l}\text { Ability to develop and } \\
\text { introduce new energy } \\
\text { storage devices, hybrid } \\
\text { energy storage systems; } \\
\text { ability to improve existing } \\
\text { energy storage devices }\end{array}$ & 5 & 5 & 5 & 1.2 \\
\hline 3 & $\begin{array}{l}\text { Ability to assess the } \\
\text { efficiency of the energy } \\
\text { infrastructure } \\
\text { enterprises }\end{array}$ & 4 & 4 & 5 & 0 \\
\hline 4 & $\begin{array}{l}\text { Ability to employ } \\
\text { techniques to improve } \\
\text { energy efficiency of } \\
\text { enterprises through the } \\
\text { use of new materials, } \\
\text { construction technologies, } \\
\text { cargo logistics techniques, } \\
\text { etc. }\end{array}$ & 4 & 4 & 4 & 5.6 \\
\hline 5 & $\begin{array}{l}\text { Ability to design new } \\
\text { efficient logistics network } \\
\text { schedules, which } \\
\text { minimize delays and } \\
\text { optimize the use of } \\
\text { employees ' working time }\end{array}$ & 2 & 3 & 4 & 0 \\
\hline 6 & $\begin{array}{l}\text { Ability to assess the } \\
\text { results of environmental } \\
\text { impact monitoring when } \\
\text { designing the field } \\
\text { development } \\
\text { operation processes and }\end{array}$ & 5 & 4 & 5 & 1.4 \\
\hline 7 & $\begin{array}{lr}\text { Ability to implement } \\
\text { introduction of new } \\
\text { technologies in different } \\
\text { spheres such as cleaning } \\
\text { and safety improving, } \\
\text { emissions controlling, } \\
\text { compliance } \\
\text { requirements monitoring } \\
\text { (including } \\
\text { developed by those } \\
\end{array}$ & 5 & 5 & 5 & 5.6 \\
\hline
\end{tabular}




\begin{tabular}{|l|l|l|l|l|c|}
\hline$\#$ & $\begin{array}{l}\text { Eco-innovative } \\
\text { competencies of mining } \\
\text { engineers }\end{array}$ & $\begin{array}{l}\text { Estimation } \\
\text { of } \\
\text { significance } \\
\text { (OZ) }\end{array}$ & $\begin{array}{l}\text { Estimation of } \\
\text { the quality of } \\
\text { competencies } \\
\text { assimilation } \\
\text { (MO) }\end{array}$ & $\begin{array}{l}\text { Maximum } \\
\text { estimation of } \\
\text { the quality of } \\
\text { competencies } \\
\text { assimilation }\end{array}$ & $\begin{array}{l}\text { Preferenc } \\
\text { e rank }\end{array}$ \\
\hline 8 & $\begin{array}{l}\text { company itself) } \\
\begin{array}{l}\text { Ability to implement eco- } \\
\text { innovations at every stage } \\
\text { of development of th } \\
\text { company's environmental } \\
\text { management system: } \\
\text { planning, organizing and } \\
\text { controlling the activities } \\
\text { of the company as a whole } \\
\text { and its individual } \\
\text { divisions (including coal } \\
\text { mining fields) }\end{array}\end{array}$ & 5 & 5 & 0 \\
\hline 9 & $\begin{array}{l}\text { Ability to develop a } \\
\text { technological cycle of } \\
\text { management that involves } \\
\text { the inclusion of innovative } \\
\text { forms of recycling and } \\
\text { waste management }\end{array}$ & 5 & 5 & 0 \\
\hline
\end{tabular}

According to the collected data, students find the quality of assimilation of the following competencies inadequate: the ability to design new efficient logistics network schedules, which minimize delays and optimize the use of employees ' working time and the ability to assess the results of environmental impact monitoring when designing the field development and operation processes. In addition, students regard the ability to assess the efficiency of the enterprises' energy infrastructure as a professional competence.

\section{Conclusion}

Eco-innovation management of organizations fully meets the challenges of emergence of "green" coal mining industry in Russia, as it is a type of strategic management, whose ultimate goal is to increase the economic efficiency of enterprises and fields, while improving the quality of life and working conditions of employees. In the long term, environmental innovations should help to increase the efficiency of environmental management and reduce the environmental burden.

As a result of the study, it should be notes that the activities of coal mining enterprises are dangerous to the environment. Eco-innovations can play a key role in minimizing the negative impact on both the external environment and the organization's staff. This paper suggests that one of the sources of effective innovation is engineers, who can put environmental values at the heart of the designed systems and products. Eco-innovation competence, therefore, is an essential component of the training of modern mining engineers.

The research results demonstrated that students experience a lack of knowledge, skills and abilities, which meet the challenges of enterprises innovative development, where they will potentially work. Therefore, in particular, the urgency of developing new thematic modules for the educational program for mining engineers is undoubtedly necessary in terms of increasing competence in the professional field [11].

We could also address this problem by introducing a completely new approach: providing practical sessions using eco-innovation modeling, work-based-learning 
technologies and project training based on simulators of real production cases. In the future, such an approach may become a topic for future research and development in the field of improving the eco-innovation education of mining engineers.

There ported study was funded by RFBR, project number 19-29-07350.

\section{References}

1. A. Dechezleprêtre, M. Sato, The impacts of environmental regulations on competitiveness, Review of Environmental Economics and Policy, 11(2), 183-206 (2017)

2. S.A.Goncharov, A.S. Voznesensky, V.L. Shkuratnik, The concept of the competence model of the specialty "Physical processes of mining or oil and gas production", Izv. higher educational. Mining journal, 5, 122-128 (2009)

3. T.C. Haab, J.C. Whitehead, What do environmental and resource economists Think? Results from a survey of AERE members. Review of Environmental Economics and Policy, 11(1), 43-58 (2017)

4. S. Evans, D. Vladimirova, M. Holgado, C.Y. Barlow, E.A. Silva, Business Model Innovation for Sustainability: Towards a Unified Perspective for Creation of Sustainable Business Models, Business Strategy and the Environment, 26(5), 597-608 (2017)

5. M. Santana, C.A. Lopez, Sustainable development and human resource management: A science mapping approach, Corporate Social Responsibility and Environmental Management, https://doi.org/10.1002/csr.1765 (2019)

6. Cl.R. Domínguez, Ig.Vill. Martínez, P.M.P. Peña, A.R. Ochoa, Analysis and evaluation of risks in underground mining using the decision matrix risk-assessment (DMRA) technique, in Guanajuato, Mexico, Journal of Sustainable Mining, 18(1), 5259 (2019)

7. S. Jarosławska-Sobór, Social potential growth of a mining company on the basis of human capital and occupational safety, Journal of Sustainable Mining, 14(4), 195-202 (2015)

8. Z.V. Apevalova, Eco-innovative management of modern enterprises in the context of the the "green economy" requirements, Economics and management of management systems, 6(4-2), 201-206 (2012)

9. Q. Zhu, Y. Qu, Y. Geng, T.A. Fujita, Comparison of Regulatory Awareness and Green Supply Chain Management Practices Among Chinese and Japanese Manufacturers, Business Strategy and the Environment, 26(1), 18-30 (2017)

10. S. Stevenazzi, M. Bonfanti, M. Masetti, S.V. Nghiem, A. Sorichetta, A versatile method for groundwater vulnerability projections in future scenarios, Journal of Environmental Management, 187, 365-374 (2017)

11. M. A. Loshchilova, V. G. Lizunkov, A. Zavyalova, Professional Training of Bachelors in Mechanical Engineering, Based on Networking Resources, Procedia - Social and Behavioral Sciences, 206, 399-405 (2015) 